\title{
Penentuan Struktur Modal Optimal Pada Perusahaan Sektor Properti, Real Estate, dan Kontruksi yang Terdaftar di Bursa Efek Indonesia
}

\author{
M. Rustam* \\ Universitas Tanjungpura
}

\begin{abstract}
ABSTRAK
The purpose of this study is to determine the optimal capital structure of property, real estate, and construction companies listed in Indonesia Stock Exchange. The motivation of this study is due to the current research results are still not able to answer whether the optimal capital structure exists. Based on trade-off theory, the optimal capital structure occurs when a company has a minimum capital cost. However, it is not explained how much capital structure needed to achieve the company maximum value. In addition, this sample business sector is chosen because there are a numeours firms with an adequate long-term debt which make it possible to examine their capital structure. The method used are the nonlinear regression and Monte Carlo simulation method. These methods were chosen because the formulation of optimal capital structure is arguably complex. There are 47 samples from all property, real estate, and construction companies. The data set covered 11 years ie (2000-2010). The results showed that the optimal capital structure of properties, real estate and construction companies which are measured by the ratio between the long-term debt and equity is 0.99 . Most companies of these sectors have not reached the optimal capital structure yet because the average results from these companies are 0.31 .
\end{abstract}

Keywords: Struktur Modal, Nilai Perusahaan, Utang Jangka Panjang.

\section{PENDAHULUAN}

Salah satu tujuan perusahaan adalah untuk memaksimumkan nilai perusahaan (Damodaran, 2001:8). Nilai suatu perusahaan dapat disamakan dengan nilai total asetnya, namun nilai yang digunakan di sini bukanlah nilai total aset menurut catatan akuntansi atau yang dikenal dengan istilah nilai buku. Penentuan nilai suatu perusahaan sering menggunakan pendekatan nilai pasar. Secara sederhana nilai pasar perusahaan adalah nilai pasar total asetnya yang diharapkan akan menghasilkan arus kas dari operasinya di masa yang akan datang atau nilai perusahaan dapat pula dinyatakan sebagai gabungan antara nilai pasar utang dan nilai pasar ekuitasnya (Damodaran 2002:37).

* Korespondensi: M. Rustam, Jurusan Manajemen, Fakultas Ekonomi, Universitas Tanjungpura, Jalan Prof. Dr. H. Hadari Nawawi, Pontianak, Indonesia. Alamat Email: m.rustam.id@ gmail.com. 
Sehubungan dengan hal tersebut, nilai suatu perusahaan atau aset berasal dari kemampuannya dalam menghasilkan arus kas di masa yang akan datang. Pengukuran nilai perusahaan dalam penelitian biasanya menggunakan proksi rasio-rasio keuangan antara lain seperti price earning ratio (PER), price to book value (PBV), atau pun rasio $\mathrm{Q}$ yaitu perbandingan antara nilai perusahaan dan nilai pengganti (replacement cost) dari total asetnya (Chung \& Pruitt, 1994). Rasio-rasio tersebut menjelaskan bahwa semakin tinggi nilainya menunjukkan semakin tinggi pula nilai perusahaan. Naiknya nilai perusahaan dapat disebabkan oleh kemampuannya dalam memperoleh laba jangka panjang dari produk atau jasa yang dihasilkan dan dijualnya serta memiliki banyak pelanggan, sedangkan turunnya nilai perusahaan dapat disebabkan karena perusahaan mengalami kesulitan finansial dan inefisiensi.

Nilai perusahaan dapat diketahui dengan menggunakan pendekatan kinerja keuangan berdasarkan pasar (market based). Kinerja keuangan berdasarkan pasar (disingkat kinerja pasar perusahaan) adalah gambaran hasil kerja perusahaan, namun bukan hanya dilihat dari laporan keuangannya saja tetapi juga dapat dilihat dari harga sekuritasnya khususnya saham yang ditawarkan di bursa. Naiknya nilai sekuritas dari suatu perusahaan dapat dipandang sebagai cerminan kinerjanya positif, sedangkan apabila nilainya turun menunjukkan kinerjanya negatif. Kinerja perusahaan yang baik dapat meningkatkan harga sahamnya di bursa, sehingga kinerja pasarnya positif. Sebaliknya apabila kinerja keuangan perusahaan buruk, maka dapat menyebabkan harga sahamnya di bursa mengalami penurunan. Pengukuran kinerja keuangan suatu perusahaan dalam penelitian dapat menggunakan data dari laporan keuangan atau dapat juga menggunakan data pasar terkait harga sekuritasnya. Selanjutnya untuk kepentingan pengukuran kinerja pasar perusahan dalam studi ini digunakan alat ukur berdasarkan pasar (market based), yaitu rasio Tobin's Q atau sering juga disebut dengan rasio Q.

Ada banyak cara dalam mengukur kinerja keuangan suatu perusahaan. Penelitipeneliti terdahulu banyak yang menggunakan data dari laporan keuangan akuntansi (accounting-based), seperti rasio return on sales (ROS), return on total assets (ROA), return on equity (ROE), dan ukuran efisiensi operasi seperti sales per employee atau net income per employee. Namun, dalam berbagai literatur alat ukur yang sangat banyak dan luas digunakan dalam mengukur kinerja keuangan perusahaan adalah dengan berdasarkan nilai pasar (market-based) seperti rasio Q, di samping alat ukur lainnya seperti price to book value, earnings per share, dan price earnings ratio (Weia \& Varela, 2003). Nilai pasar perusahaan, atau sering juga disebut sebagai nilai perusahaan dapat diestimasi dengan menghitung nilai pasar dari utang ditambah dengan nilai pasar dari ekuitas, sedangkan nilai pengganti dari total aset dapat diproksi dengan nilai buku dari seluruh aset perusahaan.

Selanjutnya dalam salah satu studi tentang pengukuran kinerja perusahaan, Lee $\&$ Ryu (2003) menggunakan rasio Q. Mereka menyebutnya rasio Q sebagai nilai perusahaan. Jo \& Harjoto (2011) mengukur nilai perusahaan juga dengan menggunakan 
rasio Q. Namun menurut istilah, nilai perusahaan seharusnya berbeda dengan rasio Q. Rasio Q hanya sebagai indikator pengukur nilai perusahaan tetapi bukan sebagai nilai perusahaan, karena nilainya berupa rasio atau skor yang tidak memiliki nama satuan, sedangkan nilai perusahaan seharusnya diukur atau dinyatakan dalam satuan moneter misalnya dolar atau rupiah, dan bukan berupa angka rasio. Kinerja keuangan dari suatu perusahaan dapat diukur dengan pendekatan berdasarkan akuntansi yaitu dengan menggunakan data berasal dari laporan keuangan dan dapat pula diukur dengan pendekatan berdasarkan nilai pasar yang diukur dengan menggunakan harga sekuritasnya di bursa.

Sehubungan dengan hal tersebut terdapat struktur modal (capital structure) yang merupakan kombinasi antara penggunaan utang dan ekuitas yang membentuk struktur pendanaan perusahaan dalam jangka panjang. Tidak seperti debt ratio atau leverage ratio yang hanya menggambarkan rasio utang dan ekuitas pada suatu saat tertentu; bagi suatu perusahaan struktur modal lebih menggambarkan target komposisi utang dan ekuitas dalam jangka panjang. Berkaitan dengan nilai perusahaan dan struktur modal ini timbul pertanyaan apakah terdapat rasio utang yang optimal bagi suatu perusahaan? Inilah pertanyaan utama dalam teori struktur modal, salah satu konsep yang penting dalam manajemen keuangan. Struktur modal yang optimal mengandung arti bahwa perusahaan menggunakan kombinasi antara utang dan ekuitas yang dapat memaksimumkan nilai perusahaan. Nilai perusahaan yang maksimum menjadi tujuan dalam manajemen keuangan karena dapat meningkatkan kekayaan pemilik (stockholders wealth).

Pencarian struktur modal yang optimal sudah sejak lama menjadi bahan pemikiran baik bagi para praktisi maupun bagi para akademisi. Hal ini berawal dari pemikiran Modigliani dan Miller (1958). Pada mulanya Modigliani dan Miller (MM) (1958) menyatakan bahwa rasio utang tidak relevan dan tidak ada struktur modal yang optimal. Nilai perusahaan tergantung pada arus kas yang akan dihasilkan dan bukan pada rasio utang dan ekuitas. Prediksi teori MM ini hanya valid apabila asumsi yang mendasarinya terpenuhi. Adapun asumsi tersebut adalah tidak ada pajak, tidak ada kesenjangan informasi, dan tidak ada biaya transaksi. Selanjutnya ketika pajak perusahaan ikut diperhitungkan, menurut teori MM justru nilai optimal perusahaan adalah jika menggunakan utang 100 persen, karena adanya penghematan pajak atas bunga utang. Hal ini sampai sekarang menjadi pemikiran para akademisi dan praktisi. Persoalan tersebut mendorong Myers (1984) menulis sebuah artikel dengan judul "The Capital Structure Puzzle" sama seperti tulisan sebelumnya yang dibuat oleh Black (1976) yang berjudul "The Dividend Puzzle" yang menyatakan dividen masih merupakan teka-teki.

Walaupun dalam kenyataannya masing-masing perusahaan memiliki struktur modal yang berbeda, ada kemungkinan memiliki suatu batas struktur modal yang optimal yaitu yang dapat memaksimumkan nilai perusahaan. Penentuan struktur modal optimal sangat penting bagi kelangsungan hidup perusahaan dalam jangka panjang. 
Sehubungan dengan hal tersebut, laporan posisi keuangan suatu perusahaan memiliki dua sisi yang seimbang. Satu sisi adalah kewajiban dan sisi lainnya adalah aset. Sisi kewajiban adalah gabungan pendanaan perusahaan yang berasal dari sumber internal dan eksternal yang telah digunakan ataupun akan digunakan untuk kelangsungan hidup perusahaan. Sisi kewajiban dibuat atas dasar pertimbangan struktur modal yang terencana. Manajer keuangan memutuskan sumber dana dari mana sebaiknya dipilih setelah mempertimbangkan faktor-faktor yang memengaruhi struktur modal. Struktur modal yang baik membuat laporan posisi keuangan perusahaan menjadi tampak kokoh. Penentuan struktur modal yang tepat atau optimal akan dapat mempertahankan kemampuan perusahaan dalam menghadapi tekanan finansial dan perubahan lingkungan pasar keuangan seperti naik turunnya suku bunga serta perubahan tarif pajak.

Apabila struktur modal optimal, maka perusahaan dapat terhindar dari risiko kesulitan keuangan. Ketika struktur modal ditentukan sebelum mendapatkan dana dari kreditur, perusahaan melakukan banyak penyesuaian untuk mengurangi risikonya. Kebanyakan perusahaan menggunakan utang sebagai sumber dananya karena sumber dana dari modal sendiri sangat terbatas. Seperti diketahui bahwa perusahaan yang berutang harus membayar kembali kewajibannya pada saat jatuh tempo dan besarnya bunga yang telah ditetapkan oleh kreditur. Perusahaan mencoba mendapatkan utang minimum jika bisnisnya baru; karena dalam bisnis yang baru biasanya rate of return-nya lebih rendah daripada tingkat bunga; dan jika meminjam lebih banyak berarti perusahaan akan menanggung risiko lebih besar, lebih banyak beban bunga, dan bahkan bisa mengalami kerugian. Apabila struktur modal dapat ditentukan dengan tepat, maka perusahaan akan dapat terhindar dari risiko kegagalan. Namun, apabila dengan berutang perusahaan akan sukses, maka perusahaan dapat meningkatkan jumlah utang yang diperkirakan dengan mengubah nilai utang dalam struktur modal. Perusahaan dapat dengan mudah membayar bunga jika return on investment dan arus kas dari bisnisnya besar. Namun manajer keuangan juga harus mempertimbangkan apakah pemegang saham lebih mengharapkan dividen atau tidak; karena dengan dividen yang tinggi tentu akan mempengaruhi arus kas dan perkembangan perusahaan pada masa yang akan datang.

Struktur modal optimal tidaklah bersifat statis. Perusahaan juga harus menyesuaikan jumlah dan sumber dana yang berbeda sesuai dengan perubahan lingkungan bisnis. Apabila pada masa yang akan datang, terjadi hambatan atau terganggunya hubungan antara perusahaan dan kreditur, maka perusahaan akan menghadapi kesulitan dalam mendapatkan dana. Namun dengan penentuan struktur modal yang fleksibel, dapat membantu perusahaan memperluas dalam mendapatkan sumber-sumber dana. Struktur modal yang fleksibel akan menciptakan mobilitas sumber dana atau dapat memaksimumkan pilihan struktur modal. Apabila bank meningkatkan suku bunga, maka perusahaan dapat mencari sumber dana lain yang lebih murah misalnya dana yang berasal dari saldo laba. 
Struktur modal yang optimal pada suatu perusahaan akan menghasilkan efisiensi terkait biaya modalnya. Apabila pasar efisien, maka hal ini akan diikuti dengan respon pasar yang positif yaitu harga sahamnya di bursa dapat mengalami kenaikan dan sekaligus dapat meningkatkan nilai perusahaannya.

Studi tentang struktur modal memang sangat menarik karena masih ada sejumlah pertanyaan yang hingga saat ini masih belum terjawab. Kajian mengenai struktur modal optimal dimulai dari artikel Modigliani \& Miller (1958), dengan serangkaian asumsi dan menyatakan bahwa struktur modal tidak memengaruhi nilai perusahaan. Teorinya disebut dengan capital structure irrelevance theory, yang kemudian diperbaiki dengan memasukkan unsur pajak. Tulisan tersebut mendorong munculnya sejumlah besar studi empiris dan teoritis; serta dapat dipandang sebagai dasar dari teori struktur modal modern. Teori struktur modal selanjutnya adalah static trade-off theory, dengan memperhitungkan adanya pajak perusahaan. Berdasarkan static trade-off theory suatu perusahaan dapat mencapai tingkat utang optimal dengan menyeimbangkan manfaat pajak atas utang (karena bunga sebagai pengurang pajak) dan potensi biaya financial distress yang meningkat bersamaan dengan tingkat utang yang lebih tinggi. Namun, static trade-off theory gagal menjelaskan beberapa kajian empiris, seperti hubungan negatif antara return on assets (ROA) dan leverage, begitu juga leverage dengan market to book ratio. Kemudian juga terjadinya penyimpangan yang besar dari tingkat utang optimal serta tingkat utang yang berbeda secara signifikan bagi perusahaan-perusahaan yang sejenis, sehingga hasil temuan itu tidak mendukung teori tersebut. Ketidakkonsistenan ini mendorong munculnya pengembangan teori struktur modal alternatif yaitu pecking order theory.

Sesuai dengan pecking order theory, dalam kondisi information asymmetry, suatu perusahaan lebih memilih menggunakan dana internal (saldo laba dan cadangan lainnya). Apabila sumber dana internal tidak lagi mencukupi, maka perusahaan menggunakan utang berisiko rendah, dan kemudian meningkat menggunakan utang yang berisiko lebih tinggi, sedangkan penggunaan ekuitas dipertimbangkan sebagai pilihan yang terakhir.

Namun, pecking order theory bukanlah satu-satunya cara untuk mengatasi kelemahan static trade-off theory. Beberapa teka-teki dapat dijawab dengan melakukan penyesuaian terhadap biaya rekapitalisasi, yang muncul karena information asymmetry dan agency problems. Hal tersebut telah mendorong munculnya dynamic trade-off theory yang menguji keputusan dalam bentuk multi-period yang memberikan ekspektasi dan mempertimbangkan biaya rekapitalisasi. Secara khusus, biaya transaksi yang timbul dari penerbitan utang dan ekuitas membuat perusahaan tidak terlalu sering menyesuaikan struktur modalnya untuk mencapai tingkat utang yang optimal. Hal tersebut mendorong perusahaan menargetkan utang optimal dalam interval tertentu dibandingkan dengan pada titik tertentu. Perusahaan menyesuaikan struktur modal hanya apabila tingkat utang berada di luar interval tersebut (Fischer \& Zechner, 1989). 
Berbeda dengan sebelumnya, studi ini dimaksudkan untuk memberikan sumbangan bagi literatur yang telah ada melalui pembuatan model prediksi struktur modal optimal dengan menggunakan model simulasi dan data panel (gabungan cross section dan time series) dari perusahaan-perusahaan terbuka di Indonesia. Pertimbangan pada model statis umumnya adalah tiga faktor yaitu keuntungan dari penghematan pajak, biaya financial distress dan agency cost. Studi ini menganalisis hubungan antara struktur modal dan kinerja pasar yang diukur dengan rasio Q. Faktor-faktor seperti penghematan pajak, biaya financial distress dan agency cost tidak dinyatakan secara eksplisit. Penentuan struktur modal optimal pada model statis berada pada point atau level tertentu. Studi ini mencoba menemukan struktur modal optimal dari tiap-tiap sektor industri menurut indeks Jakarta Stock Industrial Classification (JASICA). Pada model statis tidak dibedakan karakteristik masing-masing industri, sedangkan dalam studi ini mengkaji struktur modal optimal yang berbeda bagi masing-masing sektor industri. Penggunaan metode simulasi belum begitu banyak diterapkan dalam penelitian keuangan. Kebanyakan model yang digunakan dalam penelitian keuangan adalah regresi berganda baik linier maupun nonlinier dan sejenisnya yang sebelum penelitian dilakukan, sudah ditentukan terlebih dahulu bentuk model atau fungsinya. Namun dalam studi ini bentuk model atau fungsi ditentukan setelah data diperoleh. Salah satu model simulasi yang digunakan dalam studi ini adalah dengan teknik Monte Carlo. Metode Monte Carlo adalah suatu teknik meningkatkan jumlah sampel (resampling) dengan menggunakan probabilitas bilangan random untuk mencari solusi dari suatu masalah yang memiliki struktur yang kompleks dan bersifat stokastik atau acak namun memungkinkan untuk diprediksi. Sifat stokastik ini berlaku pula pada struktur modal yang diteliti.

Beberapa studi tentang struktur modal yang optimal ketika dibandingkan ditemukan hasil yang tidak konsisten. Sebagai contoh hasil studi Babenko (2003), yang meneliti perusahaan di Amerika, menggunakan model statis dengan mempertimbangkan financial distress. Penggunaan leverage sebagai perbandingan antara total utang dan total aset, menghasilkan perkiraan leverage optimal sebesar 38 persen, sedangkan model konvensional menghasilkan leverage optimal sebesar 73 persen. Binsbergen et al. (2011), meneliti utang optimal terhadap beberapa perusahaan di Amerika. Intensitas utang dinyatakan dalam rasio antara beban bunga utang dan nilai buku total aset. Model yang digunakan adalah keseimbangan antara marginal cost dan marginal benefit dari utang. Model tersebut menghitung biaya dan manfaat dari penggunaan utang. Hasilnya menunjukkan utang optimal berbeda-beda dikarenakan perusahaan memiliki karakteristik yang berbeda. Selain berbeda antar perusahaan, utang yang optimal juga berbeda untuk suatu perusahaan yang sama tetapi dengan tahun yang berbeda dikarenakan pengaruh pajak yang berbeda. Penggunaan model dalam penentuan struktur modal yang optimal tampak lebih kompleks. Hal ini dikarenakan faktor-faktor yang dipertimbangkan dalam penentuan struktur modal optimal tidak selalu sama, di samping hubungan faktor yang menentukan struktur modal tidak linier. Beberapa penulis 
menggunakan pendekatan dengan model differential integral yang kompleks seperti dalam tulisan Kane et al. (1985).

Berdasarkan uraian pada bagian pendahuluan, rumusan masalah yang diajukan dalam studi ini adalah berapakah struktur modal optimal pada sektor industri properti, real estate, dan konstruksi?

\section{TINJAUAN PUSTAKA}

\subsection{Struktur Modal Optimal}

Teori struktur modal modern dimulai tahun 1958, ketika Modigliani \& Miller (MM) (1958) pertama kali menyampaikan "Capital Structure Irrelevance Theory", menyatakan bahwa nilai perusahaan dan weighted average cost of capital (WACC) tidak dipengaruhi oleh struktur modal perusahaan. Namun, asumsi pasar sempurna dari MM seperti tidak ada biaya transaksi, tidak ada pajak, informasi simetris, tingkat bunga meminjam sama dengan tingkat bunga meminjamkan sebesar tingkat bunga bebas risiko adalah bertentangan dengan keadaan dalam dunia nyata.

Kemudian Modigliani \& Miller (1963) memodifikasi model awalnya dan mempertimbangkan pengurangan pajak atas bunga (tax shields effect). Sesuai dengan teori MM yang telah dimodifikasi dengan pajak, nilai perusahaan yang berutang sama dengan nilai perusahaan yang tidak berutang ditambah dengan nilai penghematan pajak karena adanya utang (tax shields). Semakin banyak utang dalam struktur modal, akan semakin tinggi nilai perusahaannya. Perusahaan selalu dapat meningkatkan nilainya dengan meningkatkan utang, yang berarti struktur modal 100 persen utang adalah optimal untuk memaksimumkan nilai perusahaan. Miller (1977) selanjutnya menambahkan pajak pribadi ke dalam analisisnya dan menunjukkan bahwa pengurangan pajak dari bunga di pihak perusahaan diimbangi dengan pajak pendapatan pribadi di pihak investor.

Perluasan model Modigliani \& Miller (1958) dan Miller (1977) adalah teori trade-off antara penghematan pajak dari berutang dan berbagai biaya yang terkait dengan utang (seperti biaya penerbitan utang, bankruptcy costs, agency costs, dan kehilangan non-debt tax shields). Bankruptcy costs ada yang bersifat langsung dan ada yang bersifat tidak langsung. Bankruptcy costs yang langsung meliputi biaya-biaya terkait dengan kebangkrutan, seperti biaya legal (menyangkut proses hukum) dan administrasi. Selanjutnya, dengan berutang, perusahaan akan menghemat pajak namun semakin besar utang akan meningkatkan risiko yang mengakibatkan peringkat utangnya menurun, dan biaya utangnya meningkat. Kemungkinan perusahaan bangkrut akan bertambah dan akhirnya harus membayar segala biayanya. Bankruptcy costs yang tidak langsung meliputi kesulitan menjalankan bisnis karena mengalami financial distress, seperti kehilangan pasar atau pelanggan, menurunnya kepercayaan pemasok, dan kinerja karyawan menurun. Selanjutnya, Jensen \& Meckling (1976) menentukan keberadaan 
agency costs yang muncul dikarenakan konflik antara manajer dan pemegang saham (agency costs of equity) atau antara pemegang saham dan debtholders (agency costs of debt).

Berdasarkan uraian tersebut, berikut adalah gambaran nilai perusahaan yang tidak menggunakan utang dan yang menggunakan utang dengan mempertimbangkan adanya financial distress dan agency cost.

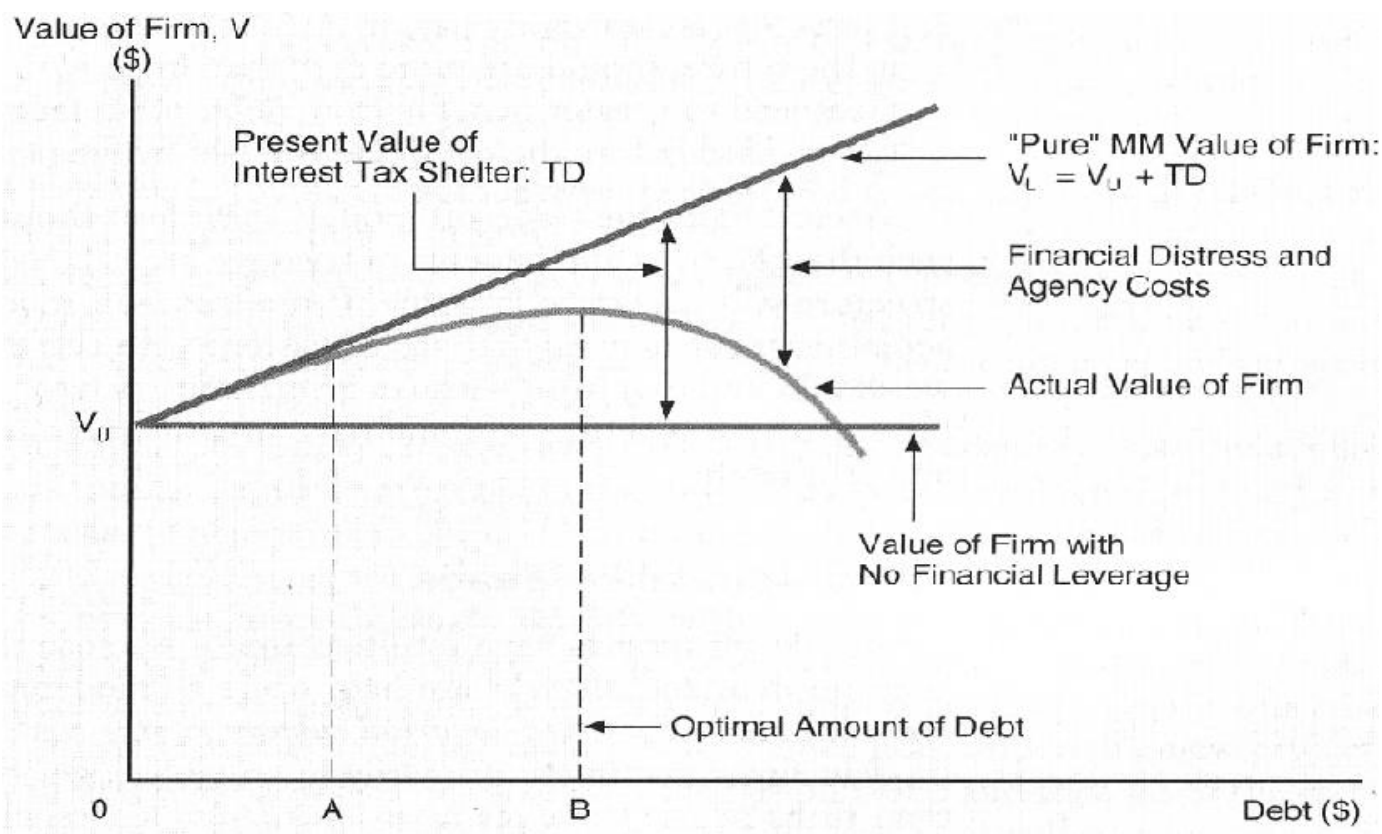

Sumber: Brigham \& Gapenski, (1997:640).

Gambar 1. Agency Cost, Tax Shield Trade-Off Model

Kraus \& Litzenberger (1973), pertama kali memperkenalkan teori static trade-off, yang menjelaskan bahwa perusahaan menyeimbangkan manfaat pajak dari bunga utang terhadap beban biaya financial distress dan kebangkrutan. Suatu titik keseimbangan antara jumlah utang dan ekuitas dalam static trade-off theory (Myers, 1977) seharusnya dipilih oleh manajer untuk diputuskan, dengan menganalisis trade-off antara manfaat menambah utang dibandingkan dengan bertambahnya biaya utang dalam bentuk financial distress atau agency costs. Hasil dari analisis tersebut akan menemukan struktur modal yang optimal. Teori ini menunjukkan bahwa manajer keuangan yang memaksimumkan nilai perusahaan seharusnya menggunakan struktur modal yang terdiri atas gabungan utang dan ekuitas. Icremental interest tax shield sama dengan incremental costs terkait pendanaan dengan menggunakan utang.

Kim \& Sorensen (1986) meneliti keberadaan agency costs dan hubungannya dengan kebijakan utang perusahaan. Mereka menemukan bahwa perusahaan dengan kepemilikan insider yang tinggi memiliki rasio utang yang lebih besar dibandingkan 
perusahaan yang kepemilikan insider-nya lebih rendah, yang dapat dijelaskan oleh agency costs of debt atau agency costs of equity. Mereka juga menemukan bahwa perusahaan yang pertumbuhannya tinggi menggunakan sedikit utang dibandingkan dengan perusahaan yang pertumbuhannya rendah, perusahaan yang risiko operasinya tinggi menggunakan lebih sedikit utang dibandingkan dengan perusahaan yang risiko operasinya rendah, sedangkan ukuran perusahaan tampaknya tidak berkorelasi dengan tingkat utang.

Hubungan antara struktur modal dan nilai perusahaan telah menjadi bahan perdebatan dalam literatur manajemen keuangan. Ada dua pertanyaan dalam hal ini yaitu: (1) Apakah ada struktur modal yang optimal bagi individu perusahaan? (2) Apakah proporsi penggunaan utang tidak memengaruhi nilai perusahaan? Castanias (1983) menyatakan bahwa kemungkinan bangkrut memiliki pengaruh negatif terhadap nilai perusahaan. Semakin meningkat proporsi utang dalam struktur modal perusahaan, kemungkinan bangkrut juga akan bertambah. Akibatnya adalah rate of return yang disyaratkan oleh bondholders meningkat mengikuti leverage. Rasio optimal dari debt to equity ditentukan dengan meningkatkan jumlah utang hingga keuntungan marginal dari leverage sama dengan kerugian marginal dari bankruptcy costs.

Jensen (1986) menekankan konflik agency antara manajer puncak dan pemegang saham. Konflik tersebut khususnya besar pada perusahaan yang memiliki free cash flows yang besar yaitu memiliki kas lebih dibandingkan dengan peluang investasi yang menguntungkan. Manajemen dapat bertindak boros atas kas dari ketidakefisienan organisasi atau melakukan investasi pada proyek-proyek yang net present value-nya kecil bahkan negatif. Peningkatan utang dalam hal ini menurunkan free cash flows, yang selanjutnya dapat meningkatkan nilai perusahaan. Leland \& Toft (1996) menunjukkan penggunaan utang jangka panjang, walaupun menghasilkan lebih banyak tax benefits, namun juga meningkatkan bankruptcy cost dan agency costs. Mereka menyatakan bahwa penggunaan utang jangka pendek mengurangi agency conflicts, dan dengan demikian akan mengurangi tingkat risiko.

Philosophov \& Philosophov (1999) mengembangkan suatu pendekatan probabilistik terhadap masalah optimalisasi struktur modal perusahaan. Pendekatan tersebut memungkinkan penaksiran rasio debt to equity yang optimal dan meliputi perhitungan probabilitas kebangkrutan perusahaan pada masa yang akan datang sebagai suatu fungsi dari sisa interval waktu hingga bangkrut. Probabilitas tersebut selanjutnya digunakan dalam suatu rumus yang dimodifikasi terkait penilaian discount share untuk menghitung share atau nilai suatu perusahaan. Selanjutnya, model struktur modal "dynamic" yang modern (Goldstein et al., 2001), memperluas model "static trade-off", mensimulasikan struktur modal optimal dengan pendekatan Monte Carlo. Kebanyakan model struktur modal tradisional menganggap bahwa keputusan berapa banyak utang akan diterbitkan adalah suatu pilihan yang statis. Kebanyakan perusahaan-perusahaan menyesuaikan tingkat utangnya untuk merespon terhadap perubahan nilai 
perusahaannya. Studi tersebut menunjukkan strategi optimal dari suatu perusahaan apabila terdapat pilihan untuk meningkatkan utang pada masa yang akan datang. Hal ini dikarenakan rasio target utang berubah sepanjang waktu, dan berarti dapat kembali kepada tingkat utang sebelumnya. Secara terpisah, perusahaan-perusahaan memperhatikan ketergantungan arus kas untuk strategi struktur modal yang arbitrer (berubah-ubah), dan para manajer memilih struktur modal yang dapat memaksimumkan kekayaan pemilik saham yang sekarang.

Berbeda dengan model trade-off, model pecking order (Myers \& Majluf, 1984) menekankan asymmetric information antara manager dan investor luar, dan memprediksi penggunaan utang dari luar disebabkan oleh defisit keuangan internal dan bukan manfaat pajak dari adanya bunga. Karena manajer memiliki informasi yang tidak dimiliki oleh investor luar, dan mereka biasanya membuat keputusan berdasarkan tujuan memaksimumkan keuntungan bagi pemilik saham, mereka mungkin akan menolak menerbitkan saham baru (ekuitas) dan utang, dan lebih memilih pendanaan internal. Sunder \& Myers (1999) selanjutnya menunjukkan perubahan struktur modal atau perubahan rasio utang disebabkan oleh kebutuhan dana eksternal, dan bukan oleh upaya untuk mencapai struktur modal yang optimal. Hasilnya adalah berupa hirarki finansial, yang mengurutkan penggunaan sumber dana mulai dari dana internal (saldo laba), utang (utang yang aman, utang yang berisiko), sampai pada ekuitas eksternal. Secara khusus, perusahaan yang menunjukkan penurunan nilai karena labanya sangat buruk dapat disebabkan memiliki utang lebih tinggi karena enggan untuk menerbitkan ekuitas baru.

Konsep terbaru yang termasuk dalam teori struktur modal adalah market timing theory. Market timing theory seperti dikemukakan oleh Baker \& Wurgler (2002) menyatakan bahwa usaha yang dilakukan dalam market timing adalah menerbitkan ekuitas pada saat harga saham overvalued tampak dari rasio market to book (M/B) relatif tinggi. Sebaliknya membeli kembali saham (repurchase) pada saat harganya undervalued. Hal ini akan berdampak kepada struktur modal perusahaan. Mereka menyatakan bahwa trade-off theory dan pecking order theory tidak konsisten dengan pengaruh negatif rata-rata tertimbang rasio $\mathrm{M} / \mathrm{B}$ terhadap leverage. Mereka menyatakan bahwa perusahaan mengatur penerbitan ekuitas menyesuaikan terhadap kondisi pasar saham. Setelah itu perusahaan tidak lagi menyesuaikan kembali target rasio utangnya karena memang perusahaan tidak mempunyai target struktur modal. Mereka menyatakan struktur modal bukanlah hasil dari strategi optimisasi yang dinamis melainkan hanyalah mencerminkan hasil kumulatif upaya masa lalu terhadap waktu pasar ekuitas.

\subsection{Kinerja Pasar}

Kinerja perusahaan memiliki makna yang luas karena dapat ditinjau dari berbagai bidang seperti pemasaran, sumber daya manusia, operasional, maupun keuangan. Namun dalam hal ini studi difokuskan pada kinerja keuangan perusahaan. Pengukuran kinerja keuangan sudah lazim diukur dengan menggunakan data keuangan suatu perusahaan 
yang diambil dari laporan keuangannya seperti laporan posisi keuangan, laporan labarugi, dan laporan arus kas. Ada beberapa metode pengukuran kinerja keuangan perusahaan di antaranya metode common size, analisis pertumbuhan, dan analisis rasio. Awalnya dalam analisis rasio sepenuhnya hanya menggunakan data dari laporan keuangan. Namun dengan keberadaan pasar modal terkait dengan analisis teknikal dan fundamental, rasio pasar turut dianalisis. Beberapa penulis membagi pengukuran kinerja keuangan dengan menggunakan rasio keuangan antara lain yang menyangkut likuiditas, aktivitas, leverage, dan profitabilitas; kemudian terakhir ditambah dengan rasio kinerja pasar. Pengukuran kinerja keuangan suatu perusahaan dapat dibedakan antara yang menggunakan data dari laporan keuangan (sering disebut dengan accounting based) dan yang menggunakan data pasar (sering disebut dengan market based). Sekarang kedua dasar tersebut sering digunakan secara bersama-sama dalam penelitian keuangan untuk mengungkapkan fenomena keuangan perusahaan.

Terdapat kebaikan dan kelemahan di antara alat ukur accounting based dan market based. Accounting based measures bersifat statis, sedangkan market based measures bersifat dinamis (dapat berubah setiap waktu). Accounting based measures lebih dapat dikendalikan oleh manajemen, sedangkan market based sulit dikendalikan ataupun direkayasa oleh manajemen; apalagi jika pasar adalah efisien.

Kinerja pasar dapat dipandang sebagai cerminan prestasi perusahaan dan menjadi reputasi perusahaan. Apabila kondisi keuangan perusahaan baik, maka akan baik pula kinerja pasarnya yang dicerminkan oleh naiknya harga sahamnya di bursa, sedangkan apabila kondisi keuangan perusahaan buruk, maka akan buruk pula kinerja pasarnya. Rasio nilai pasar berhubungan dengan perusahaan publik. Rasio-rasio nilai pasar menggambarkan keadaan ekonomi dari suatu perusahaan berdasarkan pandangan pasar. Rasio nilai pasar memberikan kepada manajemen tentang pemikiran investor terhadap perusahaan dengan mempertimbangkan kinerja perusahaan saat ini dan prospek masa depannya.

Beberapa rasio keuangan yang sering dipakai sebagai pengukur kinerja pasar adalah earnings per share, book value per share, market value per share, price earnings ratio, price to book value, price to cash ratio, dividend yield, dividend payout ratio dan juga rasio Q. Pengukuran kinerja dan hubungan satu pos dengan pos lain dalam laporan keuangan yang tampak dalam rasio-rasio keuangan dapat memberikan simpulan yang berguna dalam penentuan tingkat kesehatan keuangan suatu perusahaan. Tetapi apabila hanya memperhatikan satu alat rasio saja tidaklah cukup, sehingga harus dilakukan pula analisis pasar mengenai persaingan yang sedang dihadapi oleh manajemen perusahaan dalam industri yang lebih luas, dan dikombinasikan dengan analisis kualitatif atas bisnis dan industri, serta penelitian-penelitian terhadap industri.

Rasio Q menunjukkan bahwa nilai perusahaan yang wajar adalah yang memiliki harga sama dengan nilai total asetnya. Nilai total aset di sini menggunakan nilai replacement cost (nilai pengganti). Apabila rasio Q lebih kecil daripada satu, berarti nilai 
pasar perusahaan lebih kecil daripada nilai total asetnya dan menunjukkan perusahaan undervalued. Demikian pula sebaliknya, apabila nilainya lebih besar daripada satu, menunjukkan nilai pasar lebih tinggi daripada nilai total asetnya dan nilai perusahaan mengalami overvalued.

Sebenarnya rumus rasio $\mathrm{Q}$ cukup rumit untuk diterapkan dalam penelitian sebagaimana yang dibuat oleh Lindenberg \& Ross (disingkat L-R q) dalam Chung \& Pruitt (1994) yaitu:

L-R $\mathrm{q}=\frac{\text { PREFST }+ \text { VCOMS }+ \text { LTDEBT }+ \text { STDEBT }- \text { ADJ }}{\text { TOTASST }- \text { BKCAP }+ \text { NETCAP }}$

Keterangan:

PREFST = nilai likuidasi dari saham preferen;

VCOMS = harga saham biasa dikali dengan jumlah lembar saham yang beredar pada akhir tahun;

LTDEBT = nilai kewajiban jangka panjang disesuaikan dengan struktur umurnya;

STDEBT = nilai buku dari kewajiban lancar;

ADJ = nilai aset lancar bersih;

TOTASST $=$ nilai buku dari total aset;

BKCAP = nilai buku dari modal saham bersih;

NETCAP = nilai modal saham bersih disesuaikan dengan inflasi.

Rumus tersebut disederhanakan oleh Chung \& Pruitt (1994) kemudian disebut dengan pendekatan $\mathrm{Q}$ (approximation of $\mathrm{Q}$ ) sebagai berikut:

Approximation $Q=\frac{(M V E+P S+D E B T)}{T A}$

Keterangan:

MVE = perkalian harga saham biasa dengan jumlah lembar saham yang beredar;

PS = nilai likuidasi dari saham preferen yang beredar;

DEBT = nilai kewajiban jangka pendek bersih dari aset lancar ditambah dengan nilai buku kewajiban jangka panjang;

TA = nilai buku dari total aset.

Penelitian tersebut menunjukkan rumus proksi rasio Q ini mampu menjelaskan 96,6 persen terhadap rumus L-R q. Selain itu Klapper \& Love (2002) menggunakan rumus rasio Q yang lebih disederhanakan sebagai berikut:

Tobin's $\mathrm{Q}=\frac{\mathrm{BVA}-\mathrm{BVE}+\mathrm{MVE}}{\mathrm{BVA}}$

Keterangan:

$\mathrm{BVA}=$ Book Value of Assets

$\mathrm{BVE}=$ Book Value of Equity 


\section{MVE = Market Value of Equity}

Rumus yang sudah disederhanakan ini banyak digunakan dalam penelitian mengenai kinerja keuangan ataupun nilai perusahaan, karena lebih praktis dan sesuai dengan kondisi data yang ada. Rasio Q memiliki peran yang penting dalam menjelaskan interaksi di bidang keuangan. Formula tersebut digunakan untuk menjelaskan berbagai fenomena yang berhubungan dengan keuangan perusahaan seperti keputusan investasi dan diversifikasi (Jose et al. 1986; Malkiel et al. 1979); hubungan antara kepemilikan ekuitas oleh manajer dan nilai perusahaan (McConnell \& Servaes, 1990; dan Morck et al. 1988); hubungan antara kinerja managerial dan tender offer gains (Lang et al., 1989); peluang investasi dan respon tender offer (Lang et al., 1989); serta kebijakan pendanaan, dividen, dan kompensasi (Smith \& Watts, 1992).

\subsection{Tinjauan Penelitian Terdahulu}

Banyak studi dan penelitian yang menyatakan dampak struktur modal pada kinerja perusahaan, tetapi beberapa studi menemukan hubungan yang negatif antara struktur modal dan kinerja perusahaan (Booth et al. 2001; Deesomask et al., 2004; Huang \& Song, 2006; Karadeniz et al., 2009; Chakraborty, 2010). Beberapa studi yang lain menunjukkan hubungan yang positif antara pilihan pendanaan dan kinerja perusahaan (Ghosh et al., 2000; Hadlock \& James, 2002; Frank \& Goyal, 2003; Berger $\&$ Bonaccorsi, 2006). Selanjutnya sejumlah studi menemukan hasil yang tidak signifikan atas hubungan antara tingkat utang dan kinerja perusahaan (Tang \& Jang, 2007; Ebaid, 2009).

Walaupun demikian, semua hasil studi ini masih banyak tidak mengetahui bagaimana manajer memilih pendanaan di antara utang dan ekuitas. Harris \& Raviv (1991), dan Hovakimian et al., (2001) telah menguji hipotesis bahwa perusahaanperusahaan cenderung menuju ke suatu rasio target apabila mereka menambah modal baru atau menghentikan atau menarik kembali modal yang ada. Mereka menemukan perusahaan-perusahaan secara relatif akan menggunakan lebih banyak utang untuk membiayai aset yang digunakannya saat ini dan secara relatif lebih banyak menggunakan ekuitas untuk membiayai peluang pertumbuhan yang akan datang.

Berbagai variabel dalam pemilihan struktur modal dan struktur jatuh tempo utang akan memengaruhi kinerja suatu perusahaan. Masa jatuh tempo utang akan memengaruhi pilihan investasi bagi suatu perusahaan. Literatur tentang hubungan antara kinerja perusahaan dan struktur modal telah memberikan hasil gabungan. Abor (2005) melaporkan terdapat hubungan yang positif antara struktur modal yang diukur dengan short-term debt dan total debt, dan kinerja perusahaan selama periode 1998-2002 pada perusahaan di Ghana. Arbiyan \& Safari (2009) meneliti pengaruh struktur modal terhadap profitabilitas dengan menggunakan 100 perusahaan publik di Iran dari tahun 2001 sampai 2007. Hasil temuannya, short-term debt dan total debts berhubungan positif dengan profitabilitas (ROE) dan menunjukkan suatu hubungan negatif antara long-term 
debts dan ROE. Huang \& Song (2006) menemukan hubungan negatif antara leverage dan kinerja perusahaan (earning before interest \& tax to total assets) pada perusahaan China. Chakraborty (2010) menggunakan dua ukuran kinerja, meliputi rasio profit before interest, tax, \& depreciation to total assets dan rasio cash flows to total assets, serta dua ukuran leverage, meliputi rasio total borrowing to assets dan rasio liability terhadap ekuitas, dan menghasilkan suatu hubungan yang negatif. Ebaid (2009) meneliti tentang dampak pemilihan struktur modal terhadap kinerja 64 perusahaan dari tahun 1997 sampai 2005 di pasar modal Mesir. Ebaid menggunakan tiga ukuran accounting-based meliputi ROA, ROE, dan gross profit margin, dan menyimpulkan pemilihan struktur modal umumnya memiliki pengaruh yang lemah sampai tidak ada pengaruh terhadap kinerja perusahaan.

Studi oleh King \& Santor (2008) telah dilakukan untuk menguji hubungan antara family ownership, kinerja perusahaan, dan struktur modal di perusahaan-perusahaan Kanada. Berdasarkan rasio Q, hasilnya menunjukkan bahwa perusahaan-perusahaan yang dimiliki oleh keluarga dengan kelas saham tunggal memiliki kinerja pasar yang sama dibandingkan dengan perusahaan yang lain, yang kinerja akuntansinya superior berdasarkan ROA, dan financial leverage yang lebih tinggi berdasarkan debt to total assets. Secara perbandingan, perusahaan yang dimiliki oleh keluarga memiliki penilaian rata-rata relatif lebih rendah 17 persen dibandingkan perusahaan-perusahaan yang dimiliki oleh publik, walaupun memiliki kesamaan ROA dan financial leverage.

Studi yang dilakukan oleh San \& Teh (2011) fokus pada perusahaan konstruksi yang tercatat di Bursa Malaysia dari tahun 2005 sampai 2008, menunjukkan adanya hubungan antara struktur modal dan kinerja perusahaan. Return on capital dengan debt to equity market value dan EPS dengan long-term debt to capital memiliki hubungan yang positif, sedangkan EPS dengan debt to capital mempunyai hubungan yang negatif dan hal tersebut terjadi pada perusahaan-perusahaan besar.

Studi oleh Saeedi \& Mahmoodi (2011) menguji hubungan antara struktur modal dan kinerja perusahaan yang menggunakan sampel 320 perusahaan tercatat di bursa saham Teheran selama periode 2002 sampai 2009. Semua adalah perusahaan keuangan dan bank. Penelitiannya menggunakan empat ukuran kinerja (meliputi ROA, ROE, EPS, dan rasio Q) sebagai variabel dependen dan tiga struktur modal (meliputi rasio long-term debt, short-term debt, dan total debt) sebagai variabel independen. Hasil studinya menunjukkan bahwa kinerja perusahaan yang diukur dengan EPS dan rasio Q adalah signifikan dan positif berhubungan dengan struktur modal, antara struktur modal dan ROA mempunyai hubungan yang negatif, serta antara ROE dan struktur modal mempunyai hubungan yang tidak signifikan.

Studi oleh Pratheepkanth (2011) menganalisis struktur modal dan dampaknya terhadap kapasitas kinerja keuangan selama tahun 2005 sampai 2009 dari perusahaanperusahaan di Sri Lanka. Hasilnya menunjukkan hubungan antara struktur modal dan kinerja keuangan adalah negatif. 
Razak et al., (2008) menguji pengaruh struktur kepemilikan pengendali terhadap kinerja perusahaan yang terkait dengan pemerintah (government-linked companies (GLC)) dan Non GLC di Malaysia. Studi tersebut menggunakan data panel dengan sampel 210 perusahaan selama periode tahun 1995 sampai 2005. Hasilnya menunjukkan pengaruh yang signifikan dari kepemilikan pemerintah terhadap kinerja perusahaan setelah dilakukan kontrol terhadap karakteristik khusus perusahaan seperti ukuran perusahaan, non-duality, leverage, dan pertumbuhan.

Zeitun \& Tian (2007) meneliti pengaruh struktur modal terhadap kinerja perusahaan dengan menggunakan data panel dengan sampel 167 perusahaan Jordania selama tahun 1989 sampai 2003. Hasilnya menunjukkan bahwa struktur modal perusahaan mempunyai dampak negatif yang signifikan terhadap kinerja perusahaan, baik berdasarkan ukuran akuntansi maupun berdasarkan ukuran pasar.

Rub (2012) melakukan studi tentang pengaruh struktur modal terhadap kinerja perusahaan. Penelitiannya menggunakan lima ukuran kinerja (meliputi return on equity, return on assets, earning per share, market value of equity to the book value of equity dan rasio Q) sebagai variabel dependen dan empat ukuran struktur modal (meliputi short-term debt to total assets, long-term debt to total assets, total debt to total assets, dan total debt to total equity) sebagai variabel independen. Penelitian dilakukan dengan menggunakan sampel sebanyak 28 perusahaan yang tercatat di bursa saham Palestina selama periode tahun 2006 sampai 2010. Hasil studinya menunjukkan bahwa struktur modal perusahaan memiliki dampak positif terhadap kinerja perusahaan yang diukur berdasarkan akuntansi dan berdasarkan pasar. Secara statistik, kinerja perusahaan signifikan terhadap total debt to total assets. Market value of equity to book value of equity adalah signifikan terhadap total debt to total assets dan terhadap short-term debt to total assets. Studi ini menemukan persamaan untuk menentukan dampak berbagai utang terhadap kinerja perusahaan.

Kajian dari studi mengenai pengaruh struktur modal terhadap kinerja perusahaan menggambarkan bahwa terdapat variasi faktor pengukur struktur modal yaitu ada yang menggunakan rasio utang jangka pendek, utang jangka panjang, dan total utang terhadap total aset, serta rasio antara total utang dan total ekuitas, sedangkan faktor pengukur kinerja perusahaan ada yang menggunakan accounting based seperti ROA dan ROE serta ada pula yang menggunakan market based seperti EPS, rasio nilai pasar ekuitas terhadap nilai buku ekuitas, serta rasio Q. Begitu pula dengan hasil studinya; antara struktur modal dan kinerja perusahaan ada yang memiliki hubungan signifikan dan ada pula yang tidak signifikan. Hal ini menunjukkan bahwa hubungan antara struktur modal dan kinerja perusahaan sangat bervariasi dan masih belum jelas. Hal ini pula yang membuat teori struktur modal yang berasal dari Modigliani dan Miller masih terus diteliti oleh para akademisi. 


\section{METODE PENELITIAN}

\subsection{Populasi dan Sampel}

Berdasarkan data Bursa Efek Indonesia, jumlah keseluruhan perusahaan properti, real estat, dan konstruksi yang mencatatkan sahamnya sampai akhir tahun 2010 adalah sebanyak 47 perusahaan. Penentuan jumlah sampel dilakukan dengan metode purposive sampling karena sampel dipilih berdasarkan kriteria tertentu agar sesuai dengan syarat pengujian dan penarikan kesimpulan yang berlandaskan pada teori. Hal yang tidak sesuai dengan kriteria dan dapat mengganggu dalam penarikan kesimpulan adalah seperti nilai ekuitas perusahaan yang negatif dan tidak memiliki utang jangka panjang, serta nilai data yang ekstrim. Studi ini menggunakan sampel unbalanced panel data, terdiri atas 47 perusahaan dan jangka waktu dari tahun 2000 sampai 2010. Unbalanced panel data adalah gabungan data cross section dan time series yang jumlah data time series-nya tidak seragam. Unbalanced panel data sering digunakan sebagai rujukan dalam penelitian seperti yang pernah dilakukan oleh Baltagi \& Chang (1994).

\subsection{Teknik Pengumpulan Data}

Pengumpulan data dilakukan dengan menyalin kembali data yang diperlukan dari laporan keuangan perusahaan dalam bentuk spread sheet. Data yang dimaksud terutama yang menyangkut nilai utang jangka pendek, utang jangka panjang, ekuitas, total aset, dan harga saham dari tahun 2000 sampai 2010.

\subsection{Variabel Penelitian}

Variabel-variabel yang digunakan dalam studi ini adalah utang jangka panjang, ekuitas, ukuran perusahaan atau total aset, struktur modal, dan kinerja pasar. Variabel kinerja pasar dihitung dengan menggunakan data harga saham rata-rata dari dua tahun berurutan. Kinerja pasar sebagai proksi terhadap nilai perusahaan diukur dengan rasio Q, sedangkan struktur modal merupakan perbandingan berdasarkan nilai buku antara utang jangka panjang dan ekuitas. Data tersebut adalah data tahunan yang bersumber dari laporan keuangan perusahaan.

\subsection{Definisi Operasional Variabel}

\subsubsection{Utang jangka panjang}

Utang jangka panjang merupakan kewajiban perusahaan yang masa jatuh temponya lebih dari satu tahun. Utang ini menimbulkan beban tetap seperti beban bunga dan angsuran yang biasanya dibayar tiap bulan oleh perusahaan.

\subsubsection{Ekuitas}

Ekuitas merupakan kekayaan bersih perusahaan yang menjadi milik para pemegang saham. Ekuitas suatu perusahaan tidak memiliki masa jatuh tempo, dilaporkan 
dalam laporan posisi keuangan dan terdiri atas modal saham, saldo laba, dan dana cadangan yang akan digunakan untuk keperluan khusus bagi suatu perusahaan. Ekuitas ada yang berdasarkan nilai buku dan ada yang berdasarkan nilai pasar. Ekuitas yang berdasarkan nilai buku dapat langsung dilihat dari laporan posisi keuangan, sedangkan ekuitas berdasarkan nilai pasar, dihitung dengan mengalikan antara harga saham dengan jumlah lembar saham.

\subsubsection{Total aset}

Total aset mengambarkan besarnya kekayaan atau kepemilikan aset, baik itu aset lancar maupun aset tidak lancar seperti aktiva tetap. Aktiva tetap dapat dibedakan antara aktiva tetap berwujud dan aktiva tetap tidak berwujud seperti goodwill dan patent.

\subsubsection{Kinerja pasar}

Pengukuran kinerja keuangan perusahaan sangat beragam. Kinerja pasar perusahaan diartikan sebagai nilai pasar atau nilai jual perusahaan. Nilai ini berbeda dari nilai buku yang mudah diketahui dari laporan posisi keuangan terutama nilai total aktiva. Kinerja pasar perusahaan sangat dinamis karena nilainya ditentukan oleh harga pasar saham yang sangat fluktuatif. Kinerja pasar ini dalam banyak studi sering dikaitkan dengan harga sahamnya. Pengukuran nilai perusahaan cukup sulit, oleh karena itu sering digunakan proksi atau pendekatan. Studi ini akan menggunakan rasio Q yaitu nilai perbandingan antara nilai pasar ekuitas ditambah nilai buku total utang dibagi dengan nilai buku dari total asset (Klapper \& Love, 2002). Semakin tinggi nilai rasio ini berarti semakin tinggi kinerja pasarnya dan mengindikasikan semakin tinggi pula nilai perusahaan.

\subsubsection{Struktur modal}

Struktur modal dalam banyak literatur manajemen keuangan disepakati sebagai komposisi atau susunan modal yang digunakan dalam jangka panjang. Secara umum modal yang digunakan dalam jangka panjang adalah berasal dari utang jangka panjang (lebih dari satu tahun) dan ekuitas sebagai modal yang menjadi klaim bagi pemilik perusahaan. Kedua dana tersebut sebagai sumber dana jangka panjang bagi perusahaan. Studi ini menggunakan struktur modal sebagai perbandingan antara utang jangka panjang dan total ekuitas.

\subsection{Teknik Analisis Data}

Model analisis yang digunakan dalam studi ini adalah analisis simulasi teknik Monte Carlo. Metode Monte Carlo adalah suatu teknik yang menggunakan bilangan random dan memiliki probabilitas untuk mencari suatu solusi permasalahan yang kompleks. Istilah metode Monte Carlo diciptakan oleh Ulam dan Metropolis dalam referensi permainan yang mengandung peluang di Monte Carlo, Monaco (Metropolis and Ulam, 1949). Metropolis, mengembangkan algoritma untuk diterapkan pada komputer, mengeksplorasi permasalahan yang tidak random ke dalam bentuk random 
yang solusinya ditemukan melalui penarikan sampel random.

Cara kerja teknik Monte Carlo adalah dengan membangkitkan angka-angka random atau sampel dari suatu variabel random yang telah diketahui distribusinya. Simulasi Monte Carlo meniru kondisi nyata secara numerik. Simulasi Monte Carlo merupakan alat rekayasa yang handal untuk menyelesaikan berbagai persoalan rumit dalam bidang statistika yang mengandung probabilitas.

Peningkatan jumlah sampel dalam teknik Monte Carlo akan menurunkan deviasi standar. Cara tersebut akan menambah biaya namun manfaatnya dapat menghasilkan solusi yang lebih baik. Teknik ini menggabungkan informasi tambahan mengenai analisis secara langsung ke dalam estimasi. Hal ini memungkinkan estimasi Monte Carlo lebih baik, karena mempunyai deviasi standar yang lebih rendah.

Meskipun demikian, simulasi Monte Carlo tidak memberikan hasil yang eksak, karena pada hakekatnya simulasi Monte Carlo adalah suatu metode numerik probabilistik. Seperti pada umumnya metode numerik, simulasi Monte Carlo membutuhkan banyak sekali iterasi dan pekerjaan perhitungan. Jumlah iterasi yang dilakukan sangat menentukan tingkat ketelitian atas jawaban yang diperoleh. Metode ini sering disebut dengan metode percobaan statistik (method of statistical trials). Metode tersebut memiliki kelemahan-kelemahan, oleh karena itu sebaiknya simulasi Monte Carlo baru digunakan apabila metode analisis yang dibutuhkan tidak tersedia atau metode pendekatan (misalnya pendekatan orde pertama dari fungsi variabel random yang nonlinier) tidak memadai.

Penggunaan teknik simulasi adalah untuk mencari solusi terkait dengan persoalan kerumitan yang dihadapi atau masalahnya tidak terstruktur. Permasalahan nyata yang rumit seringkali modelnya tidak mungkin dibentuk; atau metode dan rumus yang tersedia tidak kokoh. Apabila hal ini terjadi, maka simulasi merupakan cara alternatif untuk mencari solusinya. Penggunaan simulasi menjadi semakin populer apalagi ditunjang dengan kemajuan alat hitung komputer. Pekerjaan simulasi secara statistik berlandaskan pada teori atau dalil limit pusat atau sering disebut dengan central limit theorem (dalil batas nilai tengah). Menurut Mulyono (1996), kesulitan menyelesaikan sebuah model secara analitik biasanya disebabkan oleh adanya komponen berupa variabel random. Variabel random dalam simulasi dinyatakan dengan distribusi probabilitas. Monte Carlo sampling merupakan pemilihan angka secara random dari suatu distribusi probabilitas secara resampling atau pengambilan sampel berulang. Monte Carlo menjadi suatu teknik simulasi untuk memunculkan variabel random melalui sampling dari distribusi probabilitasnya. 


\subsection{Langkah-langkah Analisis Data}

3.6.1. Penentuan Bentuk dan Fungsi Hubungan antara Variabel Struktur Modal dan Variabel Kinerja Pasar

Hubungan antara variabel bebas struktur modal dan variabel terikat kinerja pasar dalam rancangan model analisis dikaji berdasarkan pada teori dan studi empiris. Selanjutnya dengan menggunakan kedua variabel tersebut dilakukan pencarian hubungan dalam bentuk grafik dan fungsi persamaan. Bentuk grafik dan fungsi persamaan tersebut adalah antara variabel kinerja pasar (rasio Q) sebagai variabel terikat dengan notasi Y dan variabel struktur modal (debt to equity ratio) sebagai variabel bebas dengan notasi $\mathrm{X}$. Struktur modal dalam model diagram dua dimensi tersebut diletakkan posisi sumbu datar X, sedangkan kinerja pasar diletakkan pada posisi sumbu vertikal Y.

Selanjutnya untuk penghalusan hasil pembentukan fungsi asli, dilakukan resampling. Peningkatan jumlah sampel untuk kedua variabel berpasangan tersebut dilakukan dengan teknik Monte Carlo secara serempak. Cara kerja teknik Monte Carlo ini adalah dengan melakukan iterasi sampling (meniru distribusi data asli) sampai batas yang ditentukan atau yang dianggap cukup yang dalam penelitian ini dilakukan sebanyak 1.000 kali. Gambaran kinerja pasar sebagai sebuah kurva yang berbentuk cembung (convex) mempunyai suatu titik puncak sebagai titik maksimum. Melalui simulasi teknik Monte Carlo ini diperoleh suatu gambaran bentuk dan fungsi yang lebih halus yaitu hubungan antara variabel kinerja pasar dan variabel struktur modal. Gambar hubungan tersebut akan menghasilkan nilai pasar maksimum yang berarti pula struktur modalnya adalah optimal atau terbaik. Pencarian fungsi hubungan kedua variabel tersebut dilakukan pada masing-masing sektor industri berjumlah delapan sektor.

Hubungan fungsi yang diharapkan adalah berbentuk cembung (convex). Model tersebut diperoleh dari hasil simulasi penemuan bentuk gambar dan fungsi persamaan dengan bantuan software Table 2D. Pemilihan hubungan bentuk convex didasarkan pada pertimbangan yang logis. Pertimbangan yang paling diutamakan adalah bahwa fungsi persamaan yang dipilih adalah yang terbaik dengan kriteria semua nilai parameter dari struktur modal atau variabel $\mathrm{X}$ adalah signifikan atau sangat signifikan. Tingkat signifikansi ditunjukkan oleh kedua nilai hitung $\mathrm{F}$ dan $\mathrm{t}$ dengan probabilitas sebesar 0,00.

\section{TEMUAN DAN PEMBAHASAN}

\subsection{Deskripsi Data dan Analisis}

\subsubsection{Deskripsi Total Aset Perusahaan}

Total aset dapat dijadikan sebagai gambaran tentang besar kecilnya suatu perusahaan. Rata-rata keadaan total aset dari sektor properti, real estat, dan konstruksi dalam kurun waktu 2000 - 2010 adalah sebesar Rp2.596.221 juta, minimum Rp47.849 juta, maksimum Rp17.064.196 juta, dan deviasi standar Rp2.694.635juta. 


\subsubsection{Deskripsi Aktiva Tetap Bersih Perusahaan}

Aktiva tetap bersih di sini menunjukkan aktiva tetap berwujud setelah dikurangi penyusutan. Dalam kurun waktu tahun 2000 hingga 2010, sektor properti, real estat, dan konstruksi memiliki rata-rata aktiva tetap bersih sebesar Rp482.485 juta, minimum Rp161 juta, maksimum Rp5.639.422 juta, dan deviasi standar Rp714.315 juta.

\subsubsection{Deskripsi Total Utang Perusahaan}

Rata-rata keadaan total utang dari sektor properti, real estat, dan konstruksi dalam kurun waktu tahun 2000 hingga 2010 adalah sebesar Rp1.299.320 juta, minimum Rp811 juta, maksimum Rp7.975.968juta, dan deviasi standar Rp1.443.267 juta.

\subsubsection{Deskripsi Utang Jangka Panjang Perusahaan}

Rata-rata keadaan utang jangka panjang dari sektor properti real estat, dan konstruksi dalam kurun waktu tahun 2000 hingga 2010 adalah sebesar Rp316.256 juta, minimum Rp311 juta, maksimum Rp4.423.397 juta, dan deviasi standar Rp529.439 juta..

\subsubsection{Deskripsi Nilai Buku Ekuitas Perusahaan}

Rata-rata nilai buku ekuitas dari sektor sektor properti real estat, dan konstruksi dalam kurun waktu tahun 2000 hingga 2010 adalah sebesar Rp1.145.670 juta, minimum Rp47.038 juta, maksimum Rp8.021.729 juta, dan deviasi standar Rp1.247.304 juta.

\subsubsection{Deskripsi Nilai Pasar Ekuitas Perusahaan}

Rata-rata nilai pasar ekuitas dari sektor properti real estat, dan konstruksi dalam kurun waktu tahun 2000 hingga 2010 adalah sebesar Rp1.544.732 juta, minimum Rp10.138 juta, maksimum Rp15.593.517 juta, dan deviasi standar Rp2.405.719 juta.

\subsubsection{Perhitungan Struktur Modal dan Kinerja Pasar}

Struktur modal dihitung dengan membagi nilai utang jangka panjang dengan nilai ekuitas. Perhitungan kinerja pasar mengunakan rasio $Q$ yaitu membagi jumlah nilai pasar ekuitas dan nilai utang terhadap nilai total aset. Nilai pasar saham digunakan untuk memperoleh nilai pasar ekuitas. Perhitungan nilai pasar saham digunakan secara rata-rata dari dua periode (tahun) berturut-turut.

\subsubsection{Deskripsi Struktur Modal Perusahaan}

Rata-rata struktur modal sektor properti, real estat, dan konstruksi dalam kurun waktu tahun 2000 hingga 2010 adalah sebesar 31,51 persen, minimum 0,52 persen, maksimum 216,74 persen, dan deviasi standar 41,4 persen.

\subsubsection{Deskripsi Kinerja Pasar Perusahaan}

Rata-rata kinerja pasar yang diukur dengan rasio Tobin's Q dari sektor properti, 
real estat, dan konstruksi dalam kurun waktu tahun 2000 hingga 2010 adalah sebesar 1,04, minimum 0,24, maksimum 2,76, dan deviasi standar 0,43.

\subsubsection{Penentuan Struktur Modal Optimal}

Penentuan struktur modal optimal berdasarkan model statis memerlukan suatu fungsi yang menggambarkan hubungan antara kinerja pasar dan struktur modal dalam fungsi berbentuk convex (cembung). Fungsi tersebut dapat dibuat dalam jumlah banyak, namun perlu dipilih yang paling signifikan. Secara statistik, fungsi yang diperoleh perlu diuji kecocokannya melalui perhitungan koefisien determinasinya $\left(\mathrm{R}^{2}\right)$, uji $\mathrm{F}$, dan uji $\mathrm{t}$. Semakin tinggi nilai-nilai $\mathrm{R}^{2}, \mathrm{~F}$, dan $\mathrm{t}$ akan semakin baik modelnya. Dengan kata lain, semakin kecil probabilitas signifikansi uji $\mathrm{F}$ dan uji $\mathrm{t}$, semakin baik fungsi tersebut. Baik tidaknya suatu fungsi tergantung pada dispersi data observasi. Apabila dispersinya sangat tinggi, maka fungsi yang diperoleh mempunyai kualitas yang rendah, dan berarti kemampuan menjelaskan juga akan rendah. Pembentukan fungsi didahului dengan proses pencarian bentuk fungsi yang sesuai. Fungsi yang sesuai adalah yang menggambarkan hubungan antara struktur modal dan kinerja pasar dengan bentuk cembung dan memiliki koefisien regresi yang signifikan. Agar hasil regresi lebih halus, selanjutnya dari fungsi yang telah diperoleh, dilakukan simulasi dengan teknik Monte Carlo. Data yang diproses adalah nilai rasio Q dan nilai struktur modal. Resampling dilakukan pada kedua variabel tersebut (nilai rasio $Q$ dan nilai struktur modal) dengan cara pengulangan secara berpasangan hingga mencapai 1.000 kali yang diambil dari jumlah data aslinya. Penentuan jumlah resampling sebanyak 1.000 tersebut ditetapkan berdasarkan judgement yang dianggap cukup. Beberapa software telah menetapkan resampling 1.000 kali sebagai setting default-nya seperti Crystal Ball untuk menghasilkan simulasi teknik Monte Carlo. Semua proses tersebut dilakukan dengan menggunakan bantuan software Table Curve 2D dan Excel.

Gambar 2 dan 3 berikut ini menampilkan hasil sebelum dilakukan simulasi dan setelah dilakukan simulasi untuk sektor properti, real estat, dan konstruksi. Gambar 2 menunjukkan rata-rata nilai struktur modal sebelum simulasi sebesar 0,32 dan rata-rata nilai kinerja pasar sebesar 1,04. Nilai kinerja pasar maksimum adalah sebesar 2,76 dan struktur modal optimal sebesar 0,99. Setelah dilakukan simulasi, rata-rata nilai struktur modal sebesar 0,31 dan rata-rata nilai kinerja pasar sebesar 1,03. Nilai kinerja pasar maksimum adalah sebesar 2,76 dan struktur modal optimal sebesar 0,99. Walaupun perbedaan antara hasil sebelum simulasi dan sesudah simulasi tampak hampir sama, namun hasil simulasi adalah lebih baik. 


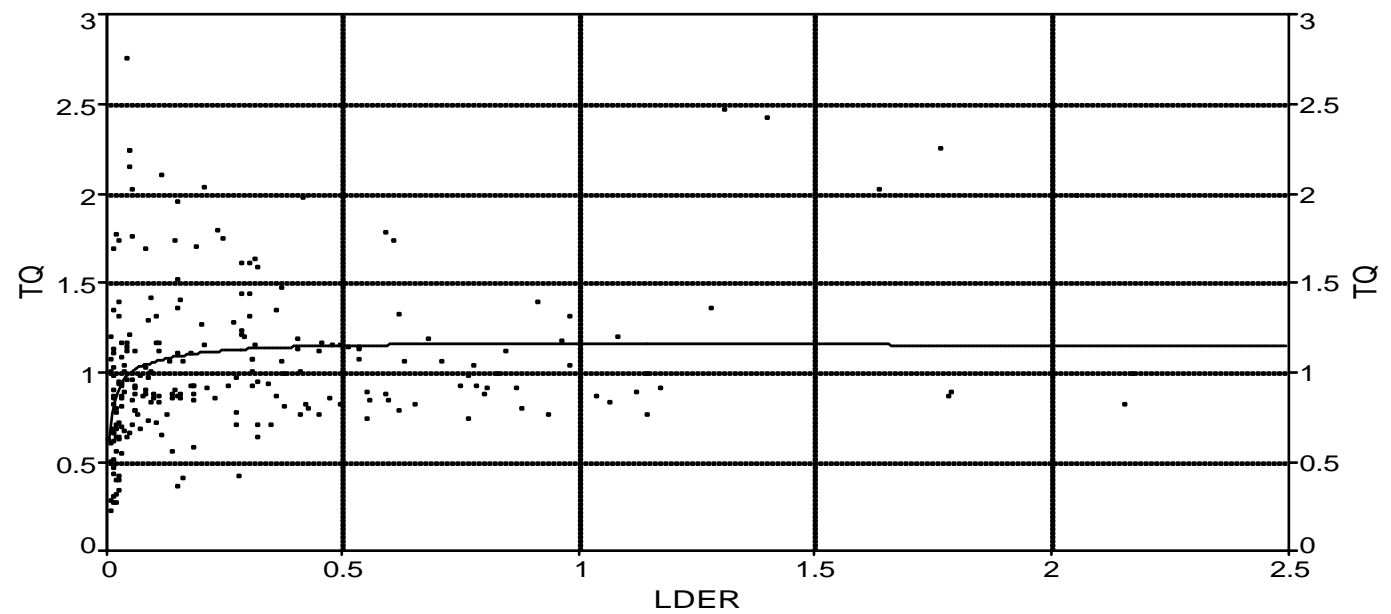

Gambar 2. Hasil Perhitungan Fungsi Sebelum Simulasi

Bentuk fungsi estimasi: $y=a+b(\ln x)^{2}$

$\begin{array}{llll}\mathrm{r}^{2} \text { Coef Det } & \text { DF Adj } \mathrm{r}^{2} & \text { Fit Std Err } & \text { F-value } \\ 0.0874236638 & 0.0796899661 & 0.4115132518 & 22.704301554\end{array}$

\begin{tabular}{lcccccc} 
Parm & Value & Std Error & t-value & \multicolumn{2}{c}{$95 \%$ Confidence Limits } & P $>|t|$ \\
a & 1.161423238 & 0.036915453 & 31.46170868 & 1.088698909 & 1.234147568 & 0.00000 \\
b & -0.01912292 & 0.004013287 & -4.76490310 & -0.02702920 & -0.01121665 & 0.00000
\end{tabular}

$\begin{array}{llll}\text { Function min } & \text { X-Value } & \text { Function max } & \text { X-Value } \\ 0.6336685723 & 0.0052298072 & 1.1614232385 & 0.9999999414\end{array}$

$\begin{array}{lllllc}\text { Source } & \text { Sum of Squares } & \text { DF } & \text { Mean Square } & \text { F Statistic } & \text { P>F } \\ \text { Regr } & 3.8448181 & 1 & 3.8448181 & 22.7043 & 0.00000 \\ \text { Error } & 40.134328 & 237 & 0.16934316 & & \\ \text { Total } & 43.979146 & 238 & & & \end{array}$

X Variable: LDER

$\begin{array}{cccccc}\text { Xmin: } & 0.0052297988 & \text { Xmax: } & 2.1674111583 & \text { Xrange: } & 2.1621813596 \\ \text { Xmean: } & 0.3150915833 & \text { Xstd: } & 0.4139759087 & \text { Xmedian: } & 0.1473414141\end{array}$

Y Variable: TQ

$\begin{array}{cccccc}\text { Ymin: } & 0.2403699818 & \text { Ymax: } & 2.7615658055 & \text { Yrange: } & 2.5211958237 \\ \text { Ymean: } & 1.0395495426 & \text { Ystd: } & 0.4298678034 & \text { Ymedian: } & 0.9359162152\end{array}$




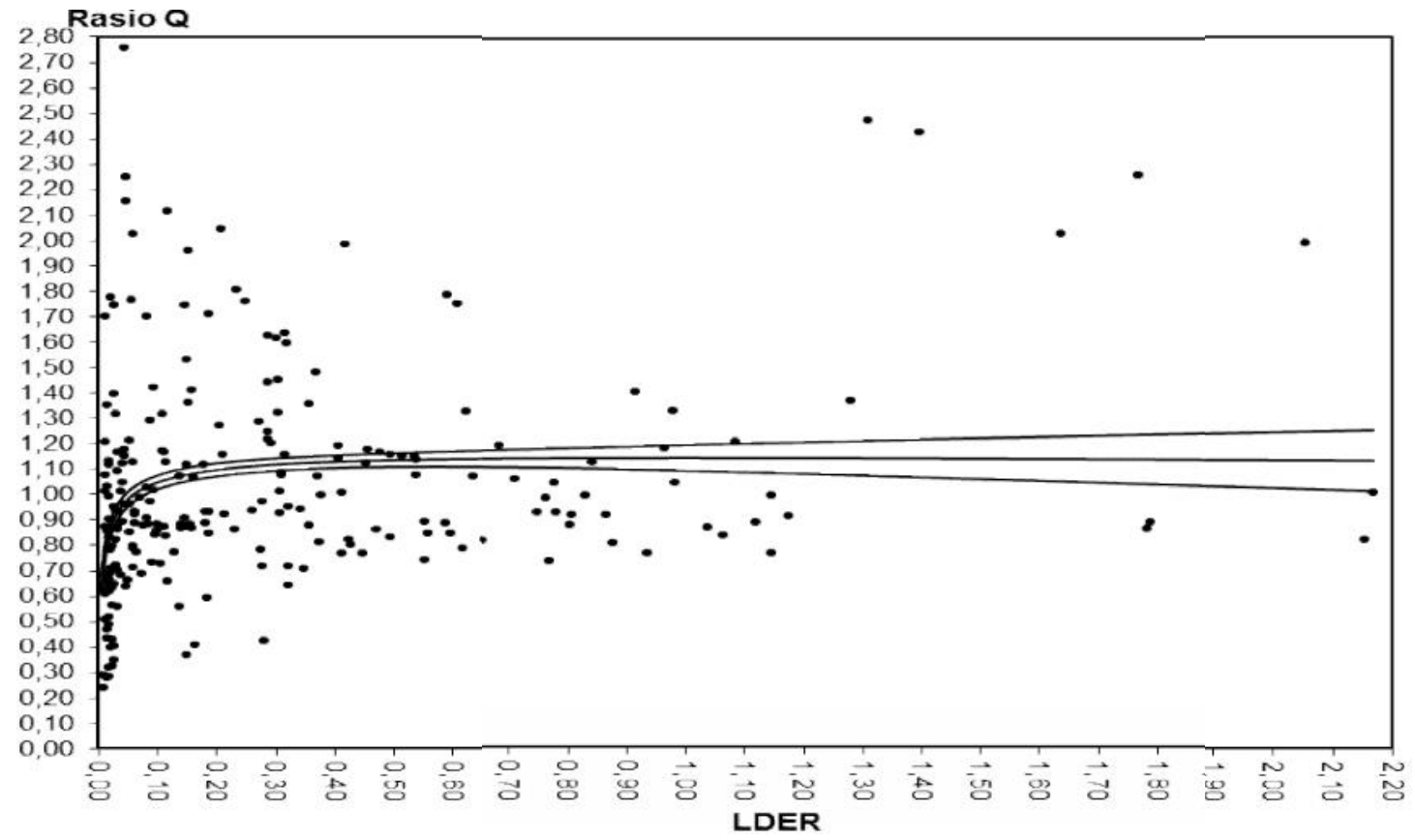

Gambar 3. Hasil Perhitungan Fungsi Setelah Dilakukan Simulasi

Uji Statistik:

$\begin{array}{llll}\mathrm{r}^{2} \text { Coef Det } & \text { DF Adj r } & \text { Fit Std Err } & \text { F-value } \\ 0.0770396731 & 0.0751881980 & 0.4020697748 & 83.303248779\end{array}$

$\begin{array}{lcccccc}\text { Parm } & \text { Value } & \text { Std Error } & \text { t-value } & 95 \% \text { Confidence Limits } & P>|t| \\ \text { a } & 1.142766274 & 0.017565643 & 65.05690009 & 1.108296442 & 1.177236105 & 0.00000 \\ \text { b } & -0.01803264 & 0.001975733 & -9.12706134 & -0.02190971 & -0.01415557 & 0.00000\end{array}$

$\begin{array}{llll}\text { Function min } & \text { X-Value } & \text { Function max } & \text { X-Value } \\ 0.6451013457 & 0.0052298072 & 1.1427662737 & 0.9999999414\end{array}$

$\begin{array}{lcrlll}\text { Source } & \text { Sum of Squares } & \text { DF } & \text { Mean Square } & \text { F Statistic } & \text { P>F } \\ \text { Regr } & 13.466812 & 1 & 13.466812 & 83.3032 & 0.00000 \\ \text { Error } & 161.33678 & 998 & 0.1616601 & & \\ \text { Total } & 174.8036 & 999 & & & \end{array}$

X Variable: LDER

$\begin{array}{llllll}\text { Xmin: } & 0.0052297988 & \text { Xmax: } & 2.1674111583 & \text { Xrange: } & 2.1621813596 \\ \text { Xmean: } & 0.3088500582 & \text { Xstd: } & 0.3939016779 & \text { Xmedian: } & 0.1462076658\end{array}$


Y Variable: TQ

$\begin{array}{cccccc}\text { Ymin: } & 0.2403699818 & \text { Ymax: } & 2.7615658055 & \text { Yrange: } & 2.5211958237 \\ \text { Ymean: } & 1.0321473046 & \text { Ystd: } & 0.4183044035 & \text { Ymedian: } & 0.9326507600\end{array}$

Kedua hasil perhitungan antara sebelum dan setelah dilakukan simulasi menunjukkan hampir tidak ada perbedaan. Hal tersebut dapat dilihat dari nilai koefisien determinasi, standard error, nilai $\mathrm{F}$, nilai X, dan nilai Y. Hasil simulasi tampak lebih baik dibandingan dengan hasil sebelum simulasi. Hal tersebut dapat dilihat dari nilai standard error yang menurun, dan nilai $\mathrm{F}$ yang meningkat. Perubahan tersebut juga memengaruhi nilai X (struktur modal) dan nilai Y (kinerja pasar) menjadi struktur modal yang optimal dan kinerja pasar yang maksimum.

Berdasarkan fungsi persamaan yang dipilih, dilakukan penggambaran ulang grafik estimasi kinerja pasar dengan menggunakan interval keyakinan sebesar $95 \%$ dari nilai rata-rata estimasi dengan rumus sebagai berikut (Supranto, 1990:252).

$$
\mathrm{Y}-\mathrm{t}_{\alpha / 2} \mathrm{~s}_{\mathrm{e}} \overline{\frac{1}{\mathrm{n}}+\frac{\mathrm{X}_{\mathrm{i}}-\mathrm{X}}{\sum \mathrm{x}_{\mathrm{i}}^{2}}} \leq \mathrm{E} \mathrm{Y} / \mathrm{X}_{\mathrm{i}} \leq \mathrm{Y}+\mathrm{t}_{\alpha / 2} \mathrm{~s}_{\mathrm{e}} \overline{\frac{1}{\mathrm{n}}+\frac{\mathrm{X}_{\mathrm{i}}-\mathrm{X}}{\sum \mathrm{x}_{\mathrm{i}}^{2}}}
$$

Keterangan:

$\mathrm{Y}=$ nilai estimasi kinerja pasar

$\mathrm{t}=$ nilai skor $\mathrm{t}$ struktur modal

$\alpha=$ tingkat signifikansi $5 \%$

$\mathrm{s}_{\mathrm{e}}=$ standard error dari estimasi kinerja pasar

$\mathrm{n}=$ jumlah sampel

$\mathrm{X}_{\mathrm{i}}=$ struktur modal individu

$\mathrm{X}=$ rata-rata struktur modal

$\mathrm{X}_{\mathrm{i}}=\mathrm{X}_{\mathrm{i}}-\mathrm{X}$

\subsection{Kinerja Pasar Maksimum Perusahaan}

Kinerja pasar maksimum yang dihitung dengan cara simulasi menunjukkan bahwa sektor properti, real estate, dan konstruksi mempunyai kinerja pasar (rasio Q) maksimum sebesar 1,14. Nilai ini dihasilkan dari regresi nonlinier kinerja pasar terhadap struktur modal. Pada saat kinerja pasar mencapai nilai maksimum, struktur modal adalah sebesar 0,99. Hal ini dapat dilihat pada Gambar di atas.

\subsection{Pembahasan}

Struktur modal yang diukur dengan membandingkan antara utang jangka panjang dan ekuitas menunjukkan hasil yang cukup menarik. Pada saat kinerja pasar sektor properti, real estat, dan konstruksi mencapai nilai maksimum, struktur modalnya menunjukkan nilai 0,99 hampir sama dengan satu. Hal ini berarti bahwa struktur modal 
optimal sektor properti, real estat, dan konstruksi adalah terjadi pada saat besarnya penggunaan utang jangka panjang sama dengan besarnya penggunaan ekuitas.

Apabila struktur modal rata-rata dibandingkan dengan struktur modal optimal, tampak bahwa secara rata-rata struktur modal yang digunakan oleh sektor properti real estat, dan konstruksi adalah belum optimal. Sebagian besar masih menggunakan utang jangka panjang sebesar 31 persen dari nilai ekuitasnya. Hal ini memberikan arti bahwa rata-rata perusahaan properti, real estat, dan konstruksi masih sangat berhati-hati dalam menggunakan utang jangka panjang walaupun penggunaan utang masih memungkinkan untuk meningkatkan nilai perusahaan. Belum optimalnya struktur modal ini dapat disebabkan oleh pihak manajemen perusahaan sebagai agent belum memandang penting arti struktur modal optimal bagi perusahaan. Manajemen masih menerapkan prinsip kehati-hatian yang berlebihan dalam penggunaan utang jangka panjang karena kekhawatiran terhadap risiko financial distress dan bankruptcy cost.

Selain itu dari gambar struktur modal optimal tampak bahwa setelah tercapai struktur modal optimal, peningkatan penggunaan utang tidak menunjukkan penurunan kinerja pasar yang tajam. Temuan ini menunjukkan bahwa peningkatan penggunaan utang jangka panjang setelah titik optimal kurang direspon oleh pasar. Hal ini berarti investor tidak memperhatikan besarnya kelebihan penggunaan utang jangka panjang oleh perusahaan sektor properti, real estat, dan konstruksi di atas batas optimal.

\section{KESIMPULAN}

Berdasarkan hasil analisis dan pembahasan mengenai penentuan struktur modal optimal perusahaan sektor properti, real estat, dan konstruksi, dengan pendekatan kinerja pasar perusahaan, dapat dirumuskan simpulan sebagai berikut. Pertama, struktur modal optimal sektor industri properti, real estat, dan konstruksi menunjukkan adanya keseimbangan antara jumlah penggunaan utang jangka panjang dan ekuitas dengan porsi julah utang jangka panjang hampir sama dengan jumlah ekuitas. Hal tersebut tampak pada hasil estimasi struktur modal optimalnya sebesar 0,99 .

Kedua, secara rata-rata, utang jangka panjang yang digunakan oleh sektor industri properti, real estate, dan konstruksi masih di bawah batas yang diperkenankan, sehingga perusahaan masih memiliki kapasitas utang (debt capacity) yang positif. Hal ini tampak pada nilai rata-rata struktur modalnya sebesar 0,31 atau penggunaan utang jangka panjang sebesar 31 persen dari jumlah ekuitas yang digunakan. Ketiga, Secara rata-rata struktur modal perusahaan sektor properti, real estat, dan konstruksi di Indonesia tampak belum optimal. Belum optimalnya struktur modal ini dapat disebabkan oleh pihak manajemen perusahaan sebagai agent belum memandang penting arti struktur modal optimal bagi perusahaan. Manajemen masih menerapkan prinsip kehati-hatian yang berlebihan dalam penggunaan utang jangka panjang karena kekhawatiran terhadap risiko financial distress dan bankruptcy cost. Selain itu tidak optimalnya struktur modal 
perusahaan dapat pula disebabkan oleh kehati-hatian dari pihak kreditur atau debt investors sebagai agent penyandang dana jangka panjang dari luar perusahaan. Padahal apabila manajemen perusahaan dapat menerapkan struktur modal yang optimal, maka akan besar sekali dampaknya bagi perkembangan perusahaan secara berkelanjutan. Perusahaan dapat bekerja lebih efisien, mampu bersaing, memperoleh profitabilitas yang tinggi, penghematan pajak optimal, kredibilitas perusahaan meningkat, dan pemegang saham mendapatkan return yang tinggi.

Berdasarkan simpulan hasil studi tersebut, saran-saran yang diajukan sebagai berikut. Bagi perusahaan-perusahaan yang struktur modalnya belum optimal dapat ditingkatkan dengan melakukan restrukturisasi pada sumber dana jangka panjangnya. Penyesuaian tersebut diharapkan dapat memaksimumkan kinerja pasar perusahaan dan agency cost dapat ditekan. Bagi investor, struktur modal optimal dapat dijadikan dasar pertimbangan dalam keputusan pemilihan investasi saham jangka panjang. Melalui investasi pada saham tersebut diharapkan dalam jangka panjang investor akan memperoleh return yang tinggi. Khusus bagi pemegang saham perusahaan yang berpengaruh, harus selalu memonitor kinerja manajemen terkait dengan keputusan struktur modal yang belum optimal.

Selain itu, bagi peneliti selanjutnya sebagai pelengkap studi tentang struktur modal dapat pula menggunakan leverage yang dalam analisisnya mengikutsertakan perhitungan utang jangka pendek. Agar hasil analisis dapat memberikan penjelasan yang lebih baik mengenai karakteristik struktur modal perusahaan, analisis dapat dirinci dengan membedakan antar subsektor industri dan juga dengan membedakan umur perusahaan.

\section{DAFTAR PUSTAKA}

Abor, J. (2005). The Effect of Capital Structure on Profitability: An Empirical Analysis of Listed Firms in Ghana. Journal of Risk Finance, 6, 438-447.

Arbiyan, A. A., \& Safari, M. (2009). The effects of Capital Structure \& Profitability in the Listed Firms in Tehran Stock Exchange. Journal of Management Perspective, $33,159-175$.

Babenko, \& Ilona. (2003). Optimal Capital Structure of the Firm in the Presence of Costs of Financial Distress. Working Paper, Haas School of Business, University of California, Berkeley, 5179, 1-44.

Baker, Malcolm, Wurgler, \& Jeffrey. (2002). Market Timing \& Capital Structure. Journal of Finance, 57(1), 1-32. 
Baltagi, B. H., \& Chang, Y. J. (1994). Incomplete Panels: A Comparative Study of Alternative Estimators for The Unbalanced One-Way Error Component Regression Model. Journal of Econometrics, 62, 67-89.

Berger, A., \& Bonaccorsi di Patti, E. (2006). Capital Structure \& Firm Performance: A New Approach to Testing Agency Theory \& An Application to the Banking Industry. Journal of Banking \& Finance, 30, 1065-1102.

Binsbergen, J. H. V., Graham, J. R., \& Yang, J. (2011). Optimal Capital Structure. Journal of Applied Corporate Finance, 23(4), 34-59.

Black, \& Fischer. (1976). The Dividend Puzzle. The Journal of Portfolio Management, $2(2), 5-8$.

Booth, L., Aivazian, V., Demirguc-Kunt, A., \& Maksimovic, V. (2001). Capital Structure in Developing Countries. The Journal of Finance, 56, 87-130.

Brigham, E. F., \& Gapenski, L. C. (1997). Financial Management - Theory \& Practice, 8 th Edition, Dryden Press.

Castanias, R. (1983). Bankruptcy Risk \& Optimal Capital Structure. The Journal of Finance, 38(5), 1617-1636.

Chakraborty, I. (2010). Capital Structure in An Emerging Stock Market: The Case of India. Research in International Business \& Finance, 24, 295-314.

Chung, K. H., \& Pruitt, S. W. (1994). A Simple Approximation of Tobin's Q. Financial Management, 23(3), 70-74.

Cooper, D. R., \& Schindler, P. S. (2003). Business Research Method. Eight Edition. New York, NY: McGraw Hill.

Damodaran, \& Aswath. (2001). Corporate Finance: Theory \& Practice. Second Edition. : John Wiley \& Sons, Inc.

Damodaran, \& Aswath. (2002). Investment Valuation: Tools \& Techniques for Determining the Value of Any Asset. Second Edition. : John Wiley \& Sons, Inc.

Deesomask, R., Paudyal, K., \& Pescetto, G. (2004). The Determinants of Capital Structure: Evidence from the Asia Pacific Region. Journal of Multinational Financial Management, 14 , 387-405.

Ebaid, E. I. (2009). The Impact of capital Structure Choice on Firm Performance: Empirical Evidence from Egypt. The Journal of Risk Finance, 10(5), 477-487.

Fischer, H. R., \& Zechner, J. (1989). Dynamic Capital Structure Choice: Theory and Tests. The Journal of Finance, 44(1), 19-40. 
Frank, M.. \& Goyal, V. (2003). Testing the Pecking Order Theory of Capital Structure. Journal of Financial Economics, 67, 217-48.

Ghosh, C., Nag, R., \& Sirmans, C. (2000). The Pricing of Seasoned Equity Offerings: Evidence from REITs. Real Estate Economics, 28, 363-384.

Goldstein, R., Ju, N., \& Leland, H. (2001). An EBIT-Based Model of Dynamic Capital Structure. Journal of Business, 74(4), 483-512.

Hadlock, C., \& James, C. (2002). Do Banks Provide Financial Slack. Journal of Finance, $57,1383-1420$.

Harris, M., \& Raviv, A. (1991). The Theory of Capital Structure. Journal of Finance, 46, 297-356.

Hovakimian, A., Opler, T., \& Titman, S. (2001). The Debt Equity Choice. Journal of Financial and Quantitative Analysis, 36(1), 1-24.

Huang, S., \& Song, F. (2006). The Determinants of Capital Structure: Evidence from China. China Economic Review, 17(1), 14-36.

IDX Fact Book 2006 - 2011, Jakarta: Bursa Efek Indonesia.

IDX Statistics 2006 - 2011, Jakarta: Bursa Efek Indonesia.

Jensen, M. C. (1986). Agency Costs of Free Cash Flow, Corporate Finance, and Takeovers. The American Economic Review, 76, 659-665.

Jensen, M. C., \& Meckling, W. (1976). Theory of the Firm: Managerial Behavior, Agency Costs, \& Ownership Structure. Journal of Financial Economics, 3(4), 305360.

Jo, Hoje \& Harjoto, M. A. (2011). Corporate Governance and Firm Value: The Impact of Corporate Social Responsibility. Journal of Business Ethics, 103(3), 351-383.

Jogiyanto, H. M. (2007). Metodologi Penelitian Bisnis: Salah Kaprah dan PengalamanPengalaman, Yogyakarta: BPFE-UGM.

Jose, M. L., Nichols, L. M., \& Stevens, J. L. (1986). Contribution of Diversification, Promotion, \& Research \& Development to the Value of Multiproduct Firms: A Tobin's Q Approach. Financial Management, 15, 33-42.

Kane, A., Marcus, A. J., \& McDonald, R. L. (1985). Debt Policy and the Rate of Return Premium to Leverage. Journal of Financial and Quantitative Analysis, 20(4), 479-499. 
Karadeniz, E., Kandir, S. Y., Balcilar, M., \& Onal, Y. B. (2009). Determinants of Capital Structure: Evidence from Turkish Lodging Companies. International Journal of Contemporary Hospitality Management, 21(5), 594-609.

Kim, W. S. \& Sorensen, E. H. (1986). Evidence on the Impact of the Agency Costs of Debt on Corporate Debt Policy. Journal of Financial and Quantitative Analysis, 21(2), 131-145.

King, M. R., \& Santor, E. (2008). Family Values: Ownership Structure, Performance and Capital Structure of Canadian Firms. Journal of Banking and Finance, 32, 24232432.

Klapper, L. F., \& Love, I. (2002), Corporate Governance, Investor Protection, and Performance in Emerging Markets. World Bank Policy Research Working Paper 2818, 1-39.

Kraus, A., \& Litzenberger, R. H. (1973). A State-Preference Model of Optimal Financial Leverage. The Journal of Finance, 28(4), 911-922.

Lang, L. H. P., Stulz, R. M., \& Walkling, R. A. (1989). Managerial Performance, Tobin's $\mathrm{Q}$, and the Gains from Successful Tender Offers. Journal of Financial Economics, 24, 137-154.

Lee, S. M., \& Ryu, K. (2003). Management Ownership and Firm's Value: An Empirical Analysis Using Panel Data. The Institute of Social and Economic Research Discussion Paper. Osaka University, 593.

Leland, H. E., \& Toft, K. B. (1996). Optimal Capital Structure, Endogenous Bankruptcy, and the Term Structure of Credit Spreads. The Journal of Finance, LI(3), 987-1019.

Malkiel, B.G., von Furstenberg, G. M., \& Watson, H. S. (1979). Expectations, Tobin's Q, and Industry Investment. Journal of Finance, 34, 549-561.

McConnell, J. J., \& Servaes, H. (1990). Additional Evidence on Equity Ownership and Corporate Value. Journal of Financial Economics, 27, 595-612.

Metropolis, N., \& Ulam, S. (1949). The Monte Carlo Method. Journal of the American Statistical Association, 44(247), 335-341.

Miller, \& Merton, (1977). Debt and Taxes. Journal of Finance, 32, 261-276.

Modigliani, F., \& Miller, M. (1958). The Cost of Capital, Corporate Finance, and the Theory of Investment. American Economics Review, 48, 261-297.

Modigliani, F., \& Miller, M. (1963). Corporate Income Taxes and the Cost of Capital: A Correction. American Economics Review, 53, 443-453. 
Morck, R., Shleifer, A., \& Vishny, R. W. (1988). Management Ownership and Market Valuation: An Empirical Analysis. Journal of Financial Economics, 20, 293-315.

Mulyono, \& Sri. (1996). Teori Pengambilan Keputusan, Edisi Revisi, Jakarta: LPFEUniversitas Indonesia.

Myers, S. C. (1977). The Determinants of Corporate Borrowing. Journal of Financial Economics, 5, 147-175.

Myers, S. C., \& Majluf, N. S. (1984). Corporate Financing and Investment Decisions when Firm Have Information and Investors Do Not Have. Journal of Financial Economics, 13(2), 187-221.

Philosophov, L.V., \& Philosophov, V.L. (1999). Optimization of Corporate Capital Structure: A Probabilistic Bayesian Approach. International Review of Financial Analysis, 8(3), 199-214.

Pratheepkanth, \& Puwanenthiren. (2011). Capital Structure and Financial Performance: Evidence from Selected Business Companies in Colombo Stock Exchange Sri Lanka. Journal of Arts, Science and Commerce, 9, 171-181.

Razak, N. H. A., Ahmad, R., \& Aliahmed, H. J. (2008). Government Ownership and Performance: An Analysis of Listed Companies in Malaysia. Corporate Ownership and Control, 6(2), 434-442.

Rub, N., \& Abu. (2012). Capital Structure and Firm Performance, Evidence from Palestine Stock Exchange. Journal of Money, Investment, and Banking, 23, 109117.

Saeedi, Ali, Mahmoodi, \& Iman. (2011). Capital Structure and Firm Performance: Evidence from Iranian Companies. International Research Journal of Finance and Economics, 70, 20-29.

San, O. T., \& Teh, B. H., (2011). Capital Structure and Corporate Performance of Malaysian Construction Sector. International Journal of Humanities and Social Science, 1(2), 28-36.

Smith, Clifford W., Jr., \& Watts, R. L. (1992). The Investment Opportunity Set and Corporate Financing, Dividend, and Cooperation Policies. Journal of Financial Economics, 32, 263-292.

Sunder, L. S., \& Myers, S. C. (1999). Testing Static Trade-off against Pecking Order Models of Capital Structure. Journal of Financial Economics, 51, 219-244.

Supranto, J. (1990). Statistik: Teori dan Aplikasi, Jilid 2, Edisi 5, Jakarta: Penerbit Erlangga. 
Tang, C. H., \& Jang, S. S. (2007). Revisit to the Determinants of Capital Structure: A Comparison between Lodging Firms and Software Firms. International Journal of Hospitality Management, 26(1), 175-187.

Weia, Z., \& Varela, O. (2003). State Equity Ownership and Firm Market Performance: Evidence from China's Newly Privatized Firms. Global Finance Journal, 14, 6582.

Zeitun, R., \& Tian, G. (2007). Capital Structure and Corporate Performance: Evidence from Jordan. Australasian Accounting Business and Finance Journal, 1, 40-50 